\title{
India's Defense Strategy and the India-ASEAN Relationship
}

\author{
DAVID BREWSTER
}

\section{Introduction}

India's defense strategy toward Southeast Asia can be understood in terms of two broad sets of strategic objectives that together drive India's relationships in the region. These include its ambitions to be the predominant power in the northeast Indian Ocean and a broader objective to assume a greater strategic role in Southeast Asia and the Pacific. India's aspirations to increase its defense presence in the region are broadly consistent with the perspectives of many ASEAN states, which mostly see India as a positive factor in the Southeast Asian balance of power. But India is yet to demonstrate itself as a useful and consistent security partner for much of the region. India is hindered by a lack of strategic focus and planning that is consistent with many of its strategic relationships.

New Delhi sees several strategic imperatives to be the predominant power in the northeast Indian Ocean, which includes the huge bay comprised of the Bay of Bengal and Andaman Sea. For India, the northeast represents a key defensive space against potential threats that may emanate from or through the Southeast Asian archipelago. The ability to control the sea lines of communication that cross the Bay of Bengal and Andaman Sea and enter the Pacific Ocean through the Malacca Strait would also provide India with considerable strategic leverage in dealing with rival powers. The area also has numerous immediate security issues that may either directly threaten India's interests or otherwise require it to act as a regional maritime security provider, including piracy and smuggling, maritime terrorism, the activities of separatist movements in Sri Lanka, Myanmar, Thailand, and India, and territorial disputes over offshore energy resources.

India's second set of strategic objectives in Southeast Asia stems from its desire to expand its strategic role in Southeast Asia and further into the Pacific. India is driven by an imperative to balance China's growing influence in Southeast Asia as well as its aspirations to expand its own strategic space. India has been relatively successful in recent years in expanding its influence in Southeast Asia in a cooperative and relatively benign manner. It has little choice but to proceed in that way. India's lack of strength compared with other major powers, particularly China, means it must remain flexible and discreet in its engagement with Southeast Asia with the expectation that its relative power will grow in coming decades.

David Brewster is a Visiting Fellow at the Strategic \& Defense Studies Center, School of International, Political \& Strategic Studies, Australian National University. 
Despite these imperatives, India does not yet have a clearly articulated strategy for its defense engagement with Southeast Asia. New Delhi has made it clear that closer defense relations with Southeast Asia is a key part of its Look East policy through which India has sought to develop a comprehensive economic, political, and security relationship with the region. At a diplomatic level, India has engaged in regional security groupings such as the ASEAN Regional Forum, the Shangri-La Dialogue and the ASEAN Defense Ministers + 8 meetings, as well as establishing regular bilateral dialogues at Defense Minister level with key states such as Singapore, Vietnam, Indonesia, Malaysia, and Thailand. New Delhi has frequently allowed the Indian Navy to lead the way in building military-to-military relationships. This has involved developing a naval presence where it could through regular exercises, coordinated patrols and ship visits. The Indian Navy has also sought to emphasize its role as a leading provider of public goods to the region, including in areas such as piracy, smuggling, maritime terrorism, and humanitarian and disaster relief. Through these means, India is seeking its gradual acceptance over time as a benign power and a preferred security partner to ASEAN, if one having a somewhat undefined role.

Although India is a strong supporter of ASEAN as a regional organization, the lack of a regional defense policy among ASEAN states means that most engagement takes place at a bilateral level. India's initial focus in expanding its influence into Southeast Asia has been on Singapore, which historically recognized India as being a natural security provider to the region. India has also had a political alliance with Vietnam stemming from the Cold War era, but which has been revived in recent years. But India will need to make considerable investments of resources and political will to develop other partners in the region, some of which have been more hesitant in recognizing India's regional security role.

\section{India's Leading Maritime Security Role in the Northeast Indian Ocean}

The starting point in any discussion of India's defense strategy in Southeast Asia is India's leading maritime security role in the northeast Indian Ocean. Key ASEAN states such as Indonesia, Malaysia, Thailand, Singapore, and Myanmar lie on or near these waters. India's role in this area is a function of its geographic advantages, its relative capabilities and its perceived strategic imperatives. India has dominated the northeast Indian Ocean since at least 1971, when the separation of Bangladesh from Pakistan removed any challenge to its position from any potential rival. India's successful naval blockade of Bangladesh severely inhibited Pakistan's ability to defend the territory and was an important reminder of the strategic consequences of control over the Bay of Bengal/Andaman Sea.

In recent years, India has been reinforcing its capabilities in the northeast Indian Ocean. Much of India's naval modernization program over the last decade has focused on improving its capabilities in the northeast. There has been an effective "rebalancing” of the proportion of defense resources committed to the India's eastern waters, reflecting relatively reduced conventional maritime threat perceptions in relation to Pakistan and relatively increased threat perceptions in relation to China. This rebalancing includes the planned construction of a major new base for the Eastern Fleet 
south of Visakhapatnam on India's east coast, with capacity for two aircraft carriers and nuclear submarines, among other things. According to Lawrence Prabhakar, an Indian naval analyst, the proposed base will have "comprehensive anti-air, anti-submarine and amphibious capability, meaning a greater allocation of priority to the emergent Chinese naval force posture in the Myanmar region.”1

India dominant strategic position in the northeast Indian Ocean is underpinned by its possession of the Andaman and Nicobar islands, which run north-south through the Andaman Sea near the western end of the Malacca Strait. As K. M. Panikkar once commented, the Andaman and Nicobar Islands potentially give India strategic bases "which if fully utilised in coordination with air power can convert the Bay of Bengal into a secure area."2 These islands also form a natural base for India to project power into the Malacca Strait and beyond into the South China Sea. They also have the potential to dominate the Malacca Strait and have been described by a Chinese naval writer as constituting a "metal chain” that could lock the western end of the Malacca Strait tight. ${ }^{3}$

Beginning in the mid-1990s, India developed extensive military facilities in the Andaman and Nicobar Islands, including port facilities to service elements of the Eastern Fleet and air bases for surveillance and strike aircraft. The operational radius of aircraft based in, or staging through, the Andamans encompasses the Malacca Strait and large portions of the South China Sea. ${ }^{4}$ Under a plan announced in 2010, there will be a major development of military infrastructure, including runway upgrades and the development of port infrastructure for use by major vessels. In addition, there will be a permanent deployment of UAVs and an expansion of the 3,500-strong army brigade to divisional strength. ${ }^{5}$ In July 2012, the Indian Navy opened a new forward air base on Great Nicobar, at the northern end of the Malacca Strait, which will be used primarily for maritime surveillance. However, the Indian Air Force has not yet permanently deployed frontline strike aircraft in the islands.

As previously noted, over the last two decades, the Indian Navy has played a leading role in developing cooperative security relationships with several ASEAN states bordering the Bay of Bengal/Andaman Sea, including through conducting joint naval patrols, bilateral exercises, and hosting the biennial MILAN "gathering” of regional navies at Port Blair in the Andaman Islands. The absence of the United States and China from the MILAN meetings is a none-too-subtle reminder of India's assertion of regional leadership. As the same time, the Indian Navy has made considerable efforts to prove itself the leading provider of public goods to the region, providing maritime security in areas such as piracy, smuggling, refugees, terrorism and separatism. The Indian Navy has also demonstrated its capabilities to provide humanitarian assistance and disaster relief to several ASEAN states, including following the 2004 Tsunami, which affected much of the northeast Indian Ocean, the 2007 Cyclone Sidr in Bangladesh, and 2008 Cyclone Nargis in Myanmar. All of these initiatives help legitimize India's naval presence in the region.

\section{Myanmar and a Chinese Presence in the Northeast Indian Ocean}

Over the last two decades, the only potential threat to India's leading position in the northeast Indian Ocean has come through Myanmar. Some see Myanmar as an essentially "contested space” in which India and China vie for it as a strategic "prize." 
But it is probably more accurate to see Myanmar as a buffer state-that is, although it may lean one way or another, it is unlikely to allow itself to be permanently incorporated into any sphere of influence. While Myanmar has tilted toward China, the political reforms that have occurred there over the last year or so seem to signal that it will take a more balanced approach in future years.

The most immediate security issue between India and Myanmar is the ethnic-based separatist insurgencies in India's Northeast States and western Myanmar. Many separatist groups live on both sides of the border and both India and Myanmar have in the past attempted to use these insurgencies as strategic leverage against the other, from time to time supporting or condoning insurgencies in the other's territory. Since the 1990s there has been intermittent and largely ineffective cooperation between India and Myanmar in cross-border counterinsurgency operations. Over this period, and particularly since 2006, India provided intelligence and limited training and equipment to Myanmar intended to either bolster the Tatmadaw's counterinsurgency capabilities or was given as quid pro quo for taking on insurgent groups. But elements of the Tatmadaw are suspected, among other things, of having significant commercial interests in the smuggling activities undertaken by Indian separatist groups and are particularly reluctant to interrupt that trade, and as a result India has little to show for its efforts. The failure of both India and Myanmar to take effective action against separatist insurgents sheltering in their territories continues to be a significant irritant in the relationship.

But India's principal long-term strategic concern with Myanmar stems from the extent of China's strategic influence there. The international isolation of Myanmar after the military junta took power in 1988 led it to turn to China as an international partner, and many analysts were concerned that this might involve the development of a Chinese strategic presence in the Northeast Indian Ocean. There were many claims that China was involved in the upgrading of several commercial ports or naval facilities, as well as the establishment of a signals intelligence facility on Great Coco Island. Although the Indian Navy has conceded that there is no Chinese intelligence facility or any Chinese naval bases anywhere in Myanmar, the issue remains a matter of significant concern for some in the Indian security community. ${ }^{6}$

The recent reforms by the Myanmar government under President Thein Sein appear to signal an important strategic shift by Myanmar, opening its relationship with the United States and India while distancing itself from China, making the potential for a Chinese security presence in the northeast Indian Ocean much less likely. Myanmar could well revert to an isolationist "prickly" neutralism that characterized the first four decades after independence, although the current signs are that it will move closer to the ASEAN economic and political model. However, either result will likely mitigate or remove a potential challenge to India's predominant strategic position in the northeast Indian Ocean.

India's Maritime Security Ambitions in the Malacca Strait

A focal point of India's maritime security ambitions in the northeast Indian Ocean is its ambitions in the Malacca Strait, which is identified by the Indian Navy as part of 
its "primary area of interest."7 The Malacca Strait is the primary route for sea traffic between the Indian and Pacific Oceans and one of the world's busiest waterways, including a projected 140,000 ship movements per annum by 2020. Around one third of global trade and the bulk of energy supplies from the Middle East to East Asia transit it. An ability to exert negative control over the Strait would be significant for India's strategic role in Southeast Asia, and indeed the entire Indian Ocean. Some claim that for India the Strait represents a rough counterpart to the strategic importance of the Panama Canal to the United States. ${ }^{8}$ Kaplan describes the Strait as being as strategically significant in coming decades as was the Fulda Gap during the Cold War. ${ }^{9}$

The ability to exert control over the Strait has both defensive and offensive implications for India. A role in Strait security is an important element in India's ability to protect its sea lines of communication into the Pacific Ocean. But negative control over the Strait could also provide India with considerable strategic leverage in any potential conflict. The Indian Navy's 2004 Maritime Doctrine argues that, "Control of the choke points could be useful as a bargaining chip in the international power game, where the currency of military power remains a stark reality."10 The Indian Ocean is the one area in which India holds a clear military advantage over China and the potential to control the Malacca Strait reinforces that advantage. As former Indian Chief of Naval Staff, Admiral Mehta, commented, “The weak area for China today is the Indian Navy. We sit in the Indian Ocean and that is a concern for China and they are not happy as it is not so easy for them to come inside."11 John Garver, an expert on Sino-Indian relations, comments: “. . . in the event of a PRC-ROI conflict, India might be tempted to escalate from the land dimension, where India might suffer reverses, to the maritime dimension, where it enjoys substantial advantages, and employ those advantages to restrict China's vital Indian Ocean trade."12

As noted previously, India's defense facilities in the Andaman and Nicobar Islands provide it with considerable measure of potential control over the western approaches to the Malacca Strait. Over the last decade India has also sought to develop an active security role-either direct or indirect-inside the Strait. At the turn of this century there were considerable concerns about piracy and the potential for maritime terrorists to block use of the Strait. In 2002, following an unsolicited request from the United States, India provided naval escorts for high-value commercial traffic through the Strait as part of the US-led Operation Enduring Freedom. India's participation in the operation was supported by Singapore (which hosted Indian naval vessels), and India is believed to have consulted Malaysia and Indonesia as well as the Philippines and Australia on the initiative. As the Chairman of the U.S. Joint Chiefs of Staff, General Pace, commented in 2006, the United States was "very comfortable with the fact that India has offered its assistance” in providing security in the Strait. ${ }^{13}$

In the early years of this century there was controversy over moves by the United States and others to take a role in providing maritime security in the Strait. This included the Regional Maritime Security Initiative under which the United States proposed to provide security in the Malacca Strait in partnership with littoral states, which was strongly opposed by Indonesia and Malaysia. Indonesia and Malaysia have also refused to formally participate in the Japanese-sponsored multilateral ReCAAP initiative involving the voluntary exchange of information on piracy and other security 
threats in the Strait. India also positioned itself as a potential benign security provider in the Strait. According to one Indian naval officer, "Our role [in the Malacca Strait] is being perceived as that of a responsible nation, which can create a balance in the region. Also, everyone realizes that India has no ambitions of hegemony." ${ }^{14}$ India has insisted that any security initiatives in the Strait must be subject to the unanimous consent of littoral states, while at the same time lobbying littoral states for an active role in the Strait both at the political and military level. ${ }^{15}$

While Singapore has generally encouraged an Indian security role, Indonesia has been somewhat ambivalent, while Malaysia has opposed it. In June 2007 Indonesian Defense Minister, Juwono Sudarsono, deflected requests from the Indian Defense Minister for a role in patrolling the Strait. ${ }^{16}$ But a 2009 meeting of the ASEAN Regional Forum in Jakarta produced an invitation to Thailand to join with Indonesia, Malaysia and Singapore in coordinated patrols of the Strait ${ }^{17}$ and an Indonesian military spokesman reportedly requested India to take part in maintaining security in the Malacca Strait, on the basis that "all approaches to the strait will be more secure for international shipping." 18 In 2010, the Indonesian Defense Minister, Purnomo Yusgiantoro, was reported as commenting that Indonesia had "no reservations at all" about India maintaining security in the Malacca Strait. ${ }^{19}$ In contrast, Malaysia has generally been opposed to allowing an Indian security role in the Strait. However, Malaysia's very cautious views toward India's naval presence in the area may have softened a little in recent years. ${ }^{20}$

Most ASEAN states now see India's defense presence in the northeast Indian Ocean in relatively benign terms and regard India as a net security provider. This contrasts with a degree of unease felt in the region during the 1980s about India's ambitious naval modernization plans and what was seen to be its opaque intentions. Regional perspectives about India also contrast sharply with perspectives on China's naval build up in the South China Sea, which is now seen as a major destabilizing factor in the region. But India's ambitions in the Malacca Strait are seen somewhat differently from its presence in the Bay of Bengal/Andaman Sea and there seems little prospect at the moment that all the littoral states will agree to giving India a direct security role in the Strait. Among other things, there are few immediate security threats (such as piracy and maritime terrorism) to be addressed and any Indian naval presence in the Strait would likely be regarded as highly provocative by China. But if the security environment changes and littoral states come under increased pressure to take action on Strait security they may allow India to participate in Strait security on their terms. Any security role for India would be a significant, not only with respect to the Malacca Strait, but also in legitimizing India's claims to be a benign security provider to the region as a whole.

\section{India's Defense Engagement With Southeast Asia}

India's second set of strategic objectives in Southeast Asia relate to its broader ambitions to expand its political and security role in the region. India is driven not only by an imperative to balance China's growing influence in Southeast Asia but also by its aspirations to expand its own strategic space into the region as part of its own growing 
economic and military power. Several Southeast Asian states are encouraging India to play a greater role in the region as a useful balance to China.

Although India has close historical links with Southeast Asia, its inward turn following Independence severely undermined its influence in the region which means that India is still making up for much lost ground. Although some in Southeast Asia in the 1960s saw India as a natural strategic partner and a potential security guarantor, consistent with its principles of nonalignment, India refused to participate in any proposed regional security arrangements. During the latter years of the Cold War, India's relationship with the Soviet Union, and its support for the Soviet Union's ally, Vietnam, reinforced India's political estrangement from the region and was a source of considerable political irritation. It is only in the last two decades that India has really sought to comprehensively engage with Southeast Asia. In the depths of India's post-Cold War economic and political crisis in 1992, the Rao government launched the "Look East Policy” which was designed to expand economic, political and security ties with Southeast Asia. India's most immediate motivation was the need to expand trade and investment links with Southeast Asia in the face of a major economic crisis.

At the political level, India's current policy is to promote the "centrality" of ASEAN in the region, which has caused it to focus on developing links with ASEANbased organizations. India became a full dialogue partner to ASEAN in 1995 and an annual India-ASEAN summit has been held since 2002. India has also sponsored new subregional organizations in the northeast Indian Ocean, including the BIMSTEC grouping ${ }^{21}$ to promote technical and economic cooperation among states in the Bay of Bengal (including Malaysia, Thailand and Myanmar), and the Mekong Ganga Cooperation group, to promote greater east-west transport connectivity between South Asia and Indochina. India's reliance on ASEAN in extending its influence into the region also means that it is an important supporter of ASEAN's role as the organizational focus of various Asia Pacific groupings. ${ }^{22}$ But a significant reduction in the relevance of ASEAN-centered institutions could ultimately lead India to opt to transcend existing regional organizations and deal directly with other major powers of the Asia Pacific. $^{23}$

India has also been a strong supporter of ASEAN-centered security arrangements. India joined the ASEAN Regional Forum (ARF) in 1996 and effectively acceded to two ASEAN-sponsored security treaties: the Nuclear Weapons Free Zone Treaty (through announcing that it would abide by the Treaty Protocol-as a non-NPT state it could not formally accede to it) and the Treaty of Amity and Cooperation (formally acceding in 2003). India also participates in the meetings of Defense Ministers of ASEAN plus Australia, China, India, Japan, New Zealand, Russia, South Korea, and the United States (known as ADMM + 8). But despite India's support for ASEAN institutions, ASEAN has only a limited role in regional security and is unlikely to assume a more significant role any time soon. This means that for the foreseeable future security engagement will largely occur at the bilateral level.

The majority of ASEAN states have, to a greater or lesser degree, welcomed an increased regional role for India, including in maritime security. Many now see India as potentially playing an important role in the regional balance of power through helping to ensure a balanced distribution of power in the region, alongside other key 
extra-regional powers such as the United States, China, Japan and Australia. Singapore, in particular, has consistently welcomed and encouraged a balanced role for external security providers on the basis that competition between major regional powers "must be squarely confronted and cannot be wished away." 24 Singapore's conception of a "balance of power" involves a multipolar balance that provides freedom to smaller states. As the Prime Minister Lee Hsien Loong has argued, Singapore's concept of a balance of power "depends on the competing interests of several big powers in the region, rather than on linking the nation's fortunes to one overbearing power. The big powers can keep one another in check, and will prevent any one of them from dominating the entire region, and so allow small states to survive in the interstices between them."25 However, aside from Singapore, a broad consensus on the importance of India's engagement in the region as a balance to China has not yet translated into close defense relationships.

The United States is also encouraging India to assume a greater role in the Southeast Asian balance of power, including through developing its defense relationships with U.S. allies and friends in the region. Washington is also actively promoting the idea of the "Indo-Pacific" as a single security region, which justifies India playing a greater political and defense role in East Asia/Pacific. In the longer term this includes potentially assuming a direct security role in the Malacca Strait and the South China Sea. The United States hopes that India might become an important political partner in East Asia, which can help bolster its efforts to temper China's strategic ambitions.

While there is a broad consensus among ASEAN states in favor of India playing a more active security role in Southeast Asia, there is no clear understanding among them as to what that role should be. To a significant extent this reflects a systemic failure of strategic coordination among ASEAN states. Nor has India melded its bilateral defense relationships with ASEAN states into a coherent regional strategy, which to a significant extent reflects New Delhi's own systemic failures in strategic planning. Rather, each of India's defense relationships with ASEAN states is currently driven more by their own dynamics and circumstances. India has relatively good defense relationships only with two states, Singapore and Vietnam, while its security relations with other states such as Indonesia, Malaysia, and Thailand remain at a relatively basic level.

As noted previously, the Indian Navy has often led the way in building military-tomilitary relationships in the region, promoting regular defense dialogues and seeking to develop a naval presence in the region through regular exercises, coordinated patrols and ship visits. ${ }^{26}$ The Indian Navy also offers its capabilities to provide public goods in areas such as piracy, smuggling, maritime terrorism, humanitarian and disaster relief, and hydrographic research. In most cases, India has sought to develop these relationships slowly and relatively informally, leaving India's desired security role largely undefined. With the partial exception of Vietnam (discussed in the following section), India has avoided developing a permanent military presence in the region.

\section{India's Key Bilateral Defense Relationships in Southeast Asia}

Over the last two decades, Singapore has positioned itself as the hub of India's economic, political and strategic relationships in Southeast Asia. ${ }^{27}$ When India announced 
its Look East policy in 1992, Singapore responded with enthusiasm and quickly positioned itself as India's de facto regional sponsor. Singapore now unquestionably plays a pivotal role in India's ambitions: it is India's regional advocate, its economic and political gateway into Southeast Asia and its most enthusiastic security partner. As Indian Defense Minister Pranab Mukherjee commented in 2006, Singapore has become "the hub of its political, economic and security strategy in the whole of East Asia."28

Singapore has made several attempts to draw India into a security role in Southeast Asia. In what was probably his first act as leader of an independent Singapore in August 1965, Lee Kwan Yew requested Indian assistance in training the newly established Singaporean army, to which New Delhi did not respond. Singapore's wish to facilitate an Indian security role in the region was revived after the end of the Cold War. As K. Kesavapany, a former senior Singaporean diplomat, put it: "India has de facto inherited the British security role” stretching from Aden to Singapore. ${ }^{29}$

Over the last decade or so, the Indian and Singapore Armed Forces have developed a relatively close relationship. In 2003, India and Singapore entered into a comprehensive defense cooperation agreement that has facilitated annual defense policy dialogues, joint exercises, intelligence sharing and cooperation in defense technology. The Singapore and Indian navies exercise together frequently, mostly in the Bay of Bengal but also in the South China Sea. Indian naval vessels are also regular visitors to Changi Naval Base. $^{30}$ The army and air forces have conducted annual exercises since 2004. The Singapore Air Force has long-term use of the Indian Kalaikunda air base and India has agreed to the stationing of Singaporean army personnel and equipment at its Babina and Deololli firing ranges. While the use of foreign facilities is nothing new for Singapore, the use of Indian territory by foreign defense forces represents a major policy shift for India which since Independence fiercely opposed any foreign military bases anywhere in Asia.

From India's perspective, Singapore's size, economic role and geographic position makes it an almost ideal partner for extending its influence in Southeast Asia. Singapore's clear-sighted approach to its own needs and the perceived needs of the region allows the relationship with India to develop without the historical or ideological baggage that could be a factor in some of India's other relationships. In strategic terms, access to Singapore's port and air facilities, in combination with India's bases in the Andaman Islands, reinforces India's position in the Malacca Strait and in the longer term could even be used to project power into the South China Sea. There are, however, some important limitations to the relationship. Singapore has close and longstanding defense relationships with others, particularly the United States and Australia. For India, Singapore's small size and its omnidirectional foreign policy means that India must develop stronger economic, political and security relationships with larger states if it wishes to have a major strategic role in the region.

India's other key defense relationship in Southeast Asia is with Vietnam. For more than forty years, India has stood with Vietnam, its "most trusted friend and ally,"31 in resisting external domination. In recent years, India has been seeking-with only limited success - to develop Vietnam as a key security partner. Some in New Delhi see an "alliance" with Vietnam, essentially aimed at China, as a quid pro quo for China's alliance with Pakistan. According to Bharat Karnad, a noted Indian nuclear strategist, 
"by cultivating a resolute Vietnam as a close regional ally and security partner in the manner China has done Pakistan, India can pay Beijing back in the same coin.”32 However, while Vietnam wants to develop India as political and economic balance to China, India is yet to prove itself as a credible a security partner to Vietnam. ${ }^{33}$

The first significant steps in developing a defense relationship with Vietnam were taken in 2000 with the formalization of a wide-ranging defense cooperation agreement. This provided for regular exchange of intelligence, joint coastguard training to combat piracy, jungle warfare and counterinsurgency training for the Indian army, repair of Vietnamese MiG aircraft, training of Vietnamese pilots and Indian assistance on small and medium arms production. But in the following years, India turned out to be a less than reliable weapons supplier. While Vietnam was initially keen on sourcing spares for Soviet-vintage equipment from India, the Indians found themselves undercut by cheap competitors and other deals have been lost through payment-related problems and Indian bureaucratic bottlenecks. There was also considerable political caution on the part of India, particularly in relation to the supply of advanced missile technology. Vietnam has formally requested the supply of Indian Prithvi intermediate range ballistic missiles and BrahMos anti-ship cruise missiles. ${ }^{34}$ India's Russian partners, however, blocked the supply of BrahMos missiles. Additionally, although the Indians reportedly agreed "in principle" to the sale of Prithvi missiles, this has subsequently stalled. ${ }^{35}$ However, Indian defense is well placed to provide training and maintenance services in relation to Russian-sourced equipment such as Vietnam's new Sukhoi aircraft and Kilo class submarines.

The key to the India-Vietnam defense relationship is the potential for an Indian naval role in the South China Sea. Indian strategists have long recognized the strategic importance of the South China Sea. ${ }^{36}$ An Indian naval presence there would allow it to respond to China's growing presence in the Indian Ocean and signal an expansion of India's area of strategic interest. Vietnam sees an Indian security presence as giving it the support of another major power in its disputes with China. Vietnam has encouraged India to effectively take a stake in the South China Sea dispute through the Indian state-owned oil company, ONGC, acquiring oil exploration permits in waters claimed by Vietnam to be within its EEZ, but which are also claimed by China. But both are also keen to avoid actions that might be overly provocative to China. As a result, India and Vietnam have conducted a dance for more than a decade, each running hot and cold over a possible Indian naval presence in the South China Sea.

In June 2011, Vietnam announced that the India Navy would be given regular access to the small port of Nha Trang, which is very close to the large naval base at Cam Ranh Bay. According to an Indian official, the Indian Navy would create what he called a "sustainable presence" presence in the South China Sea. ${ }^{37}$ But for India, there are limits to even a symbolic presence. In July 2012, the retiring Indian Naval Chief of Staff, Admiral Verma, commented that any active deployment of the Indian Navy to the Pacific and South China Sea "is not on the cards." 38 It may be that a tacit understanding will be reached between China and India not to trespass on each other's "patch"China would refrain from developing a permanent naval presence in the Indian Ocean, while India refrained from developing a presence in the South China Sea. All in all, it seems unlikely that India will never be more than a secondary security partner to 
Vietnam. India's power projection capabilities are limited and it has not demonstrated its reliability and commitment to the security relationship.

India has been slower to develop security relationships with larger states in archipelagic Southeast Asia, such as Indonesia, Malaysia, and Thailand. While they have been generally tolerant of India's strategic ambitions in the northeast Indian Ocean, they have been cautious about seeing an expanded security role for India beyond the Andaman Sea. This may inhibit the expansion of India's security role in Southeast Asia unless there is a significant change in the security environment.

India's relationship with Indonesia, though relatively undeveloped, may be a key factor to its strategic role in Southeast Asia in coming years. ${ }^{39}$ New Delhi has long perceived Indonesia, the dominant state in archipelagic Southeast Asia, as being a linchpin of any strategy to constrain Chinese influence in Southeast Asia. ${ }^{40}$ Indonesia is by far the largest state in Southeast Asia and is regarded as primus inter pares in ASEAN. It represents a big market for Indian exports as well as a major supplier of resources. A close relationship with Indonesia would enhance India's role in the region as well as helping India to develop its other relationships across Southeast Asia. Indonesia's historical concern about China also makes it a potentially important partner in balancing China's economic, political, and strategic influence in East Asia.

However engagement in the security dimension has so far been more symbolic than substantive. Since 2002, the Indian and Indonesian navies have undertaken biannual "coordinated" naval patrols in the Six-Degree Channel at the northern entrance to the Malacca Strait. Although token in practical terms, such joint action, particularly at the entrance of the Malacca Strait, has considerable symbolic value. A 2001 Defense Cooperation Agreement also provides for the supply by India of training and equipment and the development of the Indonesian defense industry. But there has been little real progress in this area, partly due to difficulties India faces in supplying jointly developed weapons (such as BrahMos cruise missiles) ${ }^{41}$ and residual sensitivities in India about Indonesia's relationship with Pakistan. However, India's Pipavav shipbuilder now has plans to build naval corvettes in Surabaya, which could also prompt greater cooperation and between the Indian and Indonesian navies in the provision of training and technology.

Indonesia's leading role in Southeast Asia, together with its geographical position as gatekeeper between the Indian and Pacific Oceans, might make it an indispensable regional partner for India. A broad-based defense partnership between India and Indonesia could transform India's role in Southeast Asia. Yet, while bilateral trade is growing quickly, both India and Indonesia are subject to significant internal constraints, which make any political or security engagement slow and hesitant. Among other things, Indonesia's small defense budget creates practical difficulties for Indonesia's armed forces. The development of a broad-based relationship with Indonesia would require a major political, economic, and security commitment by New Delhi that has so far not been forthcoming.

India's security relationships with Thailand and Malaysia are also evolving slowly. Thailand's views about maritime security in the Indian Ocean are broadly convergent with India's and Bangkok seems to accept India's strategic aspirations in the northeast Indian Ocean. But the security relationship is relatively undeveloped. Over the 
last decade or so, India provided assistance to combat Islamic separatists in Southern Thailand in return for Thai authorities taking action against Indian separatists using Thailand as an arms supply route. Since 2006, the Indian and Thai navies have also conducted symbolic “coordinated patrols” in the Andaman Sea. An MOU on Defense Cooperation was signed in January 2012 and an annual Defense Dialogue has been established. However, closer security cooperation will likely be limited by Thailand's political instability and its very limited naval capabilities in the Andaman Sea.

Malaysia, through its political and economic influence and its geographical position, is also important to India's strategic ambitions in the region. Although India gave Malaya/Malaysia considerable diplomatic support in the 1950s and 60s, the relationship became somewhat strained, particularly after Malaysia began emphasizing its ties with Muslim countries, including Pakistan. There are now several irritations in the relationship, including political unrest among the Indian ethnic community in Malaysia, unhappy with their economic and political marginalization. ${ }^{42}$ Malaysia's links with China have also sometimes caused it to be cool about including India in East Asian regional groupings; Malaysia opposed holding a separate ASEAN-India summit and quietly supported China's attempts to exclude India from the first East Asian Summit in 2005.

Malaysia has also been somewhat cautious about India's strategic ambitions in the region. Malaysia has had concerns about the level of Chinese influence in Myanmar and the potential for a Chinese naval presence in the northeast Indian Ocean. ${ }^{43}$ But neither has Kuala Lumpur always been enthusiastic about India's attempts to promote itself as the leading maritime security provider in the Andaman Sea and gain a role inside the Malacca Strait. Unlike some of its ASEAN neighbors, Malaysia considers that it has an active role to play in Indian Ocean security, as indicated by the deployment the Royal Malaysian Navy to the Gulf of Aden since 2008. Malaysia has declined to hold regular bilateral naval exercises or conduct "coordinated patrols" with the Indian Navy in the Andaman Sea in the nature of the patrols the Indian Navy conducts with Indonesia and Thailand. Although there is an MOU relating to defense cooperation, much of it remains unimplemented.

However, there is increasing cooperation in respect of shared defense platforms. Since 2007, the Indian Air Force has provided training for the Malaysian Air Force's Russian-built SU-30 MKM aircraft. There is also an agreement to cooperate in maintenance and training for the French-designed Scorpene submarines being deployed by the Malaysian and Indian navies, which could be significant in terms of relationships and interoperability. Overall, the political and economic relationship seems to be on the upswing. It is possible that as economic links with India develop Kuala Lumpur will become more comfortable with an Indian security presence in its immediate area.

\section{Conclusion}

As its varied relationships in the region attest, there is no clear Indian defense strategy towards ASEAN. Rather, this article has sought to understand India's regional relationships in terms of two broad sets of strategic objectives. The first set of objectives relate to the northeast Indian Ocean, including a perceived imperative to be the leading power in the Bay of Bengal/Andaman Sea. India also aspires to assume a direct security role 
inside the Malacca Strait in cooperation with littoral states. A second set of strategic objectives stems from a more general aspiration to expand its strategic role in Southeast Asia and further into the Pacific. This is partly to balance China, but also reflects a wish to expand India's strategic space as it grows as a major regional power.

While India promotes the centrality of ASEAN as a political and economic grouping, ASEAN's weakness in coordinating regional security policy means that the substance of defense relationships is inevitably at the bilateral level. India has neither the influence nor strategic focus to encourage ASEAN states to engage with it in a coordinated manner. As a result, India's defense relations with ASEAN states reflect their different strategic perspectives and different historical relationships with India. India has developed a close defense relationship with Singapore, which acts as its "hub" in the region. Elsewhere, India's moves have been slow and hesitant. Some in New Delhi work with Vietnam to establish an Indian naval presence in the South China Sea, but India is likely to be cautious about taking any action that could lead to a possible confrontation with China. India also aspires to develop defense relationships with Indonesia, Thailand and Malaysia, but here again the rhetoric has often exceeded the reality. If India is to build a major strategic role in the region it will need to prove itself to be a useful partner to these key states. This will require a much greater and more consistent commitment to the entire region than has been evident over the last decade or so.

\section{NOTES}

1. Sudha Ramachandran, “India Navy Drops Another Anchor,” Asia Times, October 17, 2006, http://www.atimes.com/atimes/South_Asia/HJ17Df02.html.

2. K. M. Panikkar, India and the Indian Ocean: An Essay on the Influence of Sea Power on Indian History (London: George Allen \& Unwin, 1945), p. 96.

3. Zhang Ming, “The Malacca Dilemma and the Chinese Navy's Strategic Choices,” Modern Ships Vol. 274 (October 2006), p. 23.

4. A. K. Dhar, "Indian Air Force Carries out Exercise from Andaman Islands Base,” Press Trust of India, April 15, 2005, http://www.ptinews.com.

5. Rajat Pandit, “Strategically-important A\&N Command to Get a Boost,” Times of India, February 6, 2010, http://articles.timesofindia.indiatimes.com/2010-02-06/india/28115911_1_anc-airfield-andamans.

6. "Interview with Admiral Arun Prakash, Chief of Naval Staff, Indian Navy,” Asian Defense Journal (October 2005), p. 22.

7. Indian Navy, Freedom to Use the Seas: India's Maritime Military Strategy (New Delhi: Author, May 2007.

8. James R. Holmes, Andrew C. Winner, and Toshi Yoshihara, Indian Naval Strategy in the Twenty-First Century (Abingdon: Routledge, 2009), p. 154.

9. The most likely invasion route of the Soviet Union into West Germany. Robert D. Kaplan, “Center Stage for the Twenty-First Century,” Foreign Affairs Vol. 88, No. 2 (2009), pp. 16-29, p. 25.

10. Integrated Headquarters, Ministry of Defense (Navy), Indian Maritime Doctrine (New Delhi: Author, 2004), p. 64.

11. "China afraid of India's naval presence in the Ocean,” Zeenews.com, August 13, 2009, http://zeenews.india. com/news/nation/china-afraid-of-india-s-naval-presence-in-the-ocean_555196.html.

12. John W. Garver, Protracted Contest: Sino-Indian Rivalry in the Twentieth Century (Washington: University of Washington Press, 2001), p. 277.

13. Vishnu Makhijani, “Indian Navy Awaits Regional Nod for Patrolling Malacca Straits,” Indo-Asian News Service, June 7, 2006, http://news.monstersandcritics.com/india/news/article_1170697.php/Indian_Navy_ awaits_regional_nod_for_patrolling_Malacca_Straits.

14. Gurpreet S. Khurana, “Safeguarding the Malacca Straits,” IDSA Comment, January 5, 2005, http://www.idsa. in/idsastrategiccomments/SafeguardingtheMalaccaStraits_GUKhurana_050105.

15. Shiv Aroor, “Centre Approves Navy’s Malacca Plan,” Indian Express, January 11, 2006.

16. P. S. Suryanarayana, “Indonesia for Defense Tie-Up With India,” The Hindu, June 5, 2007, http://www.hindu. com/2007/06/05/stories/2007060502201100.htm. 
17. “Thai to Join RI Patrolling Malacca Strait,” The Jakarta Post, March 5, 2009, http://www.thejakartapost.com/ news/2009/03/05/thai-join-ri-patrolling-malacca-strait.html. This conveniently extended the definition of the Malacca Strait north towards Indian waters.

18. “Indonesia Asks India to Help Maintain Malacca Strait Security,” Xinhua, March 5, 2009, http://newshopper. sulekha.com/indonesia-asks-india-to-help-maintain-malacca-strait-security_news_1043759.htm.

19. P. S. Suryanarayana, “Indonesia to "Learn” From India's Defense Sector,” The Hindu, June 18, 2010, http://www.thehindu.com/news/indonesia-to-learn-from-indias-defence-sector/article469910.ece.

20. Recent arrangements for joint training for the French Scorpene submarines being acquired by both India and Malaysia, including the training of Indian trainees at Malaysia's Kota Kinabalu naval base, represents a significant symbolic and practical development for the two navies that have had relatively little interaction in the past. "Sabah Navy Base to Be 'World's First' Scorpene Training Centre," The Malaysian Insider, October 15, 2012, http://www.themalaysianinsider.com/malaysia/article/sabah-navy-base-to-beworlds-first-scorpene-training-centre.

21. The Bay of Bengal Initiative for MultiSectoral Technical and Economic Cooperation organization.

22. Something acknowledged by Singapore's current Prime Minister. Sunanda K. Datta-Ray, Looking East to Look West: Lee Kuan Yew’s Mission India (Singapore: Penguin, 2009), p. 328.

23. Sandy Gordon, “India 'Looks East' as History,” East Asia Forum, July 17, 2010, http://www.eastasiaforum. org/2010/07/17/india-looks-east-as-history/.

24. Goh Chok Tong, "Constructing East Asia," Speech to Asia Society, 15th Asian Corporate Conference, Bangkok, June 9, 2005, http//www.asiasociety.org.

25. Brigadier-General Lee Hsien Loong, “Security Options for Small States,” Straits Times, November 6, 1984.

26. Although for historical reasons, the Indian Air Force has been the leading armed service in developing a relationship with Malaysia.

27. See, generally, David Brewster, “India’s Security Partnership with Singapore,” The Pacific Review Vol. 22, No. 5 (December 2009), pp. 597-618.

28. Pranab Mukherjee, Address to the 5th IISS Asian Security Summit, June 3, 2006, http://www.iiss.org.

29. K. Kesavapany, India's Tryst with Asia (New Delhi: Asian Institute of Transport Development, 2006), p. 48.

30. C. Raja Mohan, "India's Geopolitics and Southeast Asian Security,” Southeast Asian Affairs (2008), pp. 43-60.

31. According to Defense Minister, George Fernandes. See “India Must Not Ignore S.E. Asia: Fernandes,” The Hindu, March 28, 2000.

32. Bharat Karnad, "China Uses Pak, Vietnam Opens to India,” Express India, October 3, 2005, http:// expressindia.indianexpress.com/news/fullstory.php?newsid=55789.

33. See generally, David Brewster, "The Strategic Relationship Between India and Vietnam: The Search for a Diamond on the South China Sea?” Asian Security Vol. 5, Issue 1 (January 2009), pp. 24-44.

34. India Defense Consultants, "What's Hot?_-Analysis of Recent Happenings—Indian Navy Update," IDC Analysis, November 20, 2005, http://www.indiadefense.com/whatshot.html.

35. Rahul Bedi, “Strategic Realignments,” Frontline Vol. 20, Issue 13 (2003), http///www.frontline.in.

36. Panikkar, India and the Indian Ocean (see note 2 above), p. 85.

37. Sridhar Kumaraswami, “India Eyes South China Sea Pearl,” Asian Age, June 26, 2011, http://archive.asianage. com/india/india-eyes-south-china-sea-pearl-563.

38. Gautam Datt, "India Against Direct Intervention in South China Sea Disputes Despite Having Stakes in the Region,” India Today, August 8, 2012, http://indiatoday.intoday.in/story/south-china-sea-india-agaianstdirect-intervention-in-disputes/1/212305.html.

39. See generally, David Brewster, “The Evolving Security Relationship Between India and Indonesia,” Asian Survey Vol. 51, No. 2 (March/April 2011), pp. 221-244.

40. Mohammed Ayoob, India and Southeast Asia: Indian Perceptions and Policies (London: Routledge, 1990), p. 36.

41. "Indonesia and Malaysia Keen on Buying Brahmos,” Frontier India Strategic and Defense, April 13, 2007, http://www.frontierindia.net.

42. Dr. V. Suryanarayan, "Malaysian Indian Society in Ferment," South Asia Analysis Group, Paper No. 2880, October 14, 2008, http://southasiaanalysis.org.

43. Bertil Lintner, “Enter the Dragon,” Far Eastern Economic Review, December 22, 1994, p. 24. 